\title{
Notas sobre a autonomia relativa do professor e seu cerceamento constante ${ }^{119}$
}

\author{
João Wanderley Geraldi ${ }^{120}$
}

\section{Submetido e aprovado em maio de 2016.}

\author{
A professora \\ ainda intentou corrigir. \\ Nhamizua, porém, insistiu: \\ - a ordem dos tractores é arbitrária. \\ Errara na frase, acertara na ideia. \\ Para ele, \\ tractor era coisa \\ que nunca haveria de acontecer. \\ E arrematou: \\ é assim, professora: \\ uns são videntes \\ outros duvidentes.
}

(Mia Couto. Arbitrária Desordem)

Meu objetivo nestas notas sobre a autonomia relativa do professor é discutir a situação atual do ofício de professor e os cerceamentos que cercam o exercício da profissão, alterando a identidade profissional que já passou, ao longo da história, por diversas concepções.

A prática pedagógica se realiza numa relação triangular entre professores e alunos e conhecimentos. As práticas hegemônicas nas escolas resultam sempre do foco em um destes três vértices que permanecem enquanto tais, ainda que a definição de cada um dos seus elementos se modifique constantemente. Na história, nem sempre fomos os mesmos professores; nossos alunos nem sempre foram os que são hoje; os conhecimentos que constituem nossa herança cultural se alteram não só pelos resultados de uma pesquisa normal, mas também se revolucionam quando são postas em questão

\footnotetext{
${ }^{119}$ Palestra proferida para sindicalistas da Associação de Professores do Paraná, Curitiba, 15.04.2016.

${ }^{120}$ Professor Titular aposentado da Unicamp. jwgeraldi@yahoo.com.br 
os fundamentos epistêmicos da própria ciência, como vem ocorrendo neste fim da era moderna.

Há dificuldades em falar de autonomia. O termo recobre realidades distintas.

Uma simples olhada no dicionário nos revela isso:

\begin{abstract}
Autonomia. [Do gr. Autonomia.] S. f. 1. Faculdade de se governar por si mesmo. 2. Direito ou faculdade de se reger (uma nação) por leis próprias. 3. Liberdade ou independência moral ou intelectual. 4. Distância máxima que um veículo, um avião ou um navio pode percorrer sem se reabastecer de combustível. 5. Ét. Propriedade pela qual o homem pretende poder escolher as leis que regem sua conduta. [Cf. heteronomia.] (Novo Dicionário Aurélio)
\end{abstract}

Como se pode ver, remete-se a outros conceitos tão vagos ou imprecisos quanto ele mesmo: faculdade, direito, lei, liberdade, independência. Na Retórica, estes são chamados de conceitos confusos que permitem uma argumentação que pode dançar segundo o ethos do orador e segundo o que pressupõe como valores de seu auditório.

Mas há algo que podemos detectar de imediato: a autonomia faz referência ao "eu" e ao "outro" apesar do aparente sentido de remessa somente ao próprio sujeito, enquanto sua faculdade ou sua escolha. Ao remeter a condutas, a leis, o conceito remete aos outros, ao conjunto dos outros dentro do qual estamos e em que nos comportamos 'autonomamente'. Isto significa que a autonomia, como a liberdade, tem uma existência sempre relativa aos outros que nos circundam, mas que, numa sociedade democrática, não nos cerceiam. Ninguém é autônomo, ponto. Todos somos autônomos na relação com os outros e em determinadas ações que praticamos. Somos, por exemplo, leitores autônomos quando temos diante de nós um texto, literário ou não. Teremos menor autonomia diante de um texto científico. E seremos leitores absolutamente não autônomos diante de um texto da física contemporânea, e demandaremos neste caso a mediação de um físico. E eis que emerge outro conceito necessário para pensar a autonomia: a mediação.

\title{
A AUTONOMIA DO PROFESSOR
}

Podemos tomar como ponto de partida que a autonomia do professor, em sua prática pedagógica - as ações na relação professor-aluno-conhecimentos - é sempre relativa. Enumeremos aqui os espaços sociais que constroem esta relatividade:

1. A sociedade, que define para si as funções da escola, o que deseja como educação de seus filhos, de seus cidadãos.

Ora, dito assim sem matizes, parece que a sociedade é algo uniforme, constituída por gente unida, com os mesmos interesses, com os meus objetivos, sem contradições. 
Desde logo há uma contradição entre sociedade e indivíduo. No interior da sociedade, não somos sujeitos situados nos mesmos espaços: há diferenças de posições sociais, políticas, ideológicas etc. Há uma luta constante no interior de uma sociedade que faz dela não um organismo, metáfora que esconde o fato biológico de que todo organismo vivo é autorregulador e autodefensivo ${ }^{121}$. A luta constante está sempre a mostrar que a organização da sociedade, seu modo de existir, suas perspectivas são da ordem instrumental, isto é, construídas historicamente para realizar o objetivo primeiro da sobrevivência de todos, mas da forma como negociado em seu interior, supostamente para permitir a cada um uma sobrevivência feliz e... autônoma.

A escola é uma instituição social construída ao longo do tempo (tal como a conhecemos, bastante recente) para 'educar' crianças e jovens tanto para que se insiram 'adequadamente' no meio social, quanto para que se façam agentes da manutenção de uma herança cultural. Ambos os propósitos são extremamente movediços. Que seria uma inserção social 'adequada'? Do meu ponto de vista, seria a do jovem escolarizado que elabora com coerência críticas ao modelo de vida que se leva, tornando-se força de transformação social; para outros, esta inserção nada tem a ver com crítica, mas com preparo para o sucesso 'no mercado', seja o mercado da produção intelectual, seja ele o mercado de trabalho. Obviamente, esquece-se um pequeno pormenor: há aqueles que terão sucesso no mercado (e nem é de trabalho) pelas heranças que recebem... E estes também são 'educados’ pela escola!!! Estes querem uma formação não crítica, mas mantenedora da "ordem arbitrária dos tratores"!

Quanto ao segundo propósito da instituição escolar - a conservação de uma herança cultural - aparentemente a discussão é menos problemática e até às vezes parece que há pensamentos unânimes a seu respeito. Em geral porque há uma ideologia que funda esta unanimidade: os conhecimentos a serem transmitidos na escola são conhecimentos científicos! São estes, não outros. Acontece que há inúmeras heranças culturais. Quem seleciona aquelas que devem fazer parte do currículo escolar? É esta seleção que transforma conhecimentos científicos em conteúdos de ensino. Os conteúdos de ensino não são da ordem do conhecimento científico, mas da ordem da seleção de certos conhecimentos tomados de forma pouco científica, porque tomados como verdades. No mundo da ciência, opera-se com hipóteses. No mundo da escola, com verdades estabelecidas 'pela ciência". Enquanto a ciência, por natureza, não se fixa

\footnotetext{
${ }^{121}$ Esta metáfora está muito em voga, por causa do pensamento neoliberal e sua defesa do mercado, como se este pudesse se autorregular e autopreservar como se fora um organismo biológico e não um fenômeno social.
} 
no estabelecido e vive dos duvidentes, à escola a dúvida é repugnante. Enquanto há dúvida, segundo a escola, não se aprendeu! Dou um exemplo. A professora ensinou o conceito de "pronomes de tratamento". E pergunta à sala:

- "Você" que tipo de pronome é?

Um dos alunos responde

- Pronome do caso reto.

A sala ri, a professora corrige, porque o aluno ainda não aprendeu a resposta certa!!! Acontece que na aula anterior a professora tinha ensinado o que eram pronomes do caso reto e pronomes do caso oblíquo. Ora, todo e qualquer pronome de tratamento somente ocorre no "caso reto" e se esta classificação deve ser considerada para os pronomes que remetem a pessoas (do discurso ou da situação), então todos os pronomes de tratamento estão sempre no caso reto! Mas aquilo que o 'duvidente' falou é desconsiderado, é tomado como erro, porque só existe uma verdade, aquela ensinada. Por isso é difícil aprender com os alunos, afinal eles estão ali para aprender porque não sabem...

\section{Os conhecimentos e suas seriações}

O segundo conjunto de cerceamentos que tem tradição na escola é a seriação dos conhecimentos, a partir de uma imagem que se tem do aprendiz e do processo de aprendizagem: deve partir do simples para o complexo! Como se a criança vivesse num mundo familiar simples!!! Os conhecimentos não só são selecionados, mas reorganizados segundo um critério que nada tem do processo de sua própria produção. Na ciência, um conhecimento é produzido na relação e "duvidência' de conhecimentos estabelecidos e os resultados não são organizados segundo sua complexidade ou segundo uma seriação qualquer; são simplesmente apresentados como resultados. Assim, por exemplo, os velhos gramáticos faziam ciência taxionômica, classificavam tudo. Ao organizarem seus critérios de classificação e seus tipos, não afirmaram que a o 'substantivo comum' é menos complexo que o 'substantivo composto', ou que classificação das orações coordenadas é menos complexa do que a classificação das orações subordinadas...

Estas seriações fazem com que os acontecimentos de sala de aula que poderiam abrir horizontes de novas aprendizagens, que os interesses momentâneos dos alunos, que a presença estranha de qualquer ser na escola e no seu pátio, nada pode ser tomado como ponto de partida para aprendizagens que não sejam aquelas já previstas no programa, no conteúdo daquela série. Se responder a uma questão vai além do previsto, 
dá-se uma resposta superficial para que o aluno se contente com o pouco que se lhe dá (sub-repticiamente estamos educando para aceitar o pouco em outros níveis!). Quando um acontecimento não sai da cabeça dos alunos, a professora/o professor faz uma ginástica mental enorme para ligar algo deste acontecimento com algo do que "tem que ensinar".

\section{A disciplina}

A herança cultural de que dispomos foi construída dentro de diferentes disciplinas, compartimentalizando os saberes disponíveis. Nossa formação de professores segue esta compartimentalização. A escola se organiza segundo esta compartimentalização. E o aluno tem que se virar porque tem que transitar por todos os compartimentos com eficiência para ser aprovado. Nós escolhemos a área de nossos cursos superiores, mas jamais admitimos que os alunos dos níveis mais baixos que o universitário tenham escolhas. Nós nos (in)formamos dentro da compartimentalização e nos especializamos num compartimento. Mas a vida não é compartimentalizada. Nem os fenômenos naturais, humanos, sociais são compartimentalizados. Nem os alunos...

Depois de a escola nos encher de conhecimentos que dispensaremos no futuro, decidimos fazer nosso curso superior. Aliás, para entrar nele temos que mostrar conhecimentos que nada terão a ver com o que vamos estudar logo depois: esta barreira da entrada tem sua função de manutenção da forma de organização curricular da escola moderna.

Foucault analisou a disciplina como um mecanismo de controle interno dos discursos que podem ser proferidos no interior de uma área, de um campo. Aqui estamos analisando a organização disciplinar dos conteúdos e dos currículos como um mecanismo de controle de ação pedagógica. Às vezes, não podemos sequer fazer uso do que aprendemos na escola básica em outras disciplinas para trabalhar em nossa própria disciplina. Um professor de língua portuguesa só pode levar um mapa para sua sala de aula quando está tratando da expansão da língua portuguesa pelo mundo, ou quando está estudando a origem das línguas românicas (e aí terá que ser um mapa histórico!). Se não forem estes os temas, um mapa-mundi não é considerado material didático da aula de português!

\section{A circulação de conhecimentos fora da escola}


Os pais de nossos alunos também sofreram a mesma escolarização, e muito frequentemente querem que seus filhos sigam o mesmo processo que seguiram: aprendam o que aprenderam, e aprendam como aprenderam. Esta permanência do passado no presente está também no próprio exercício da nossa profissão. Todos nos lembramos de nossos professores, e quando nos tornamos professores queremos nos identificar com aqueles de que nós mesmos gostamos quando alunos, e queremos estar muito distantes daqueles que detestamos, que achamos ruins. Todo homem é o que foi, o que está sendo e o que será. Por isso somos seres históricos e em cada um de nós esta micro-história da vida é lembrança, é memória. Não nos desfazemos delas, porque se desfazer delas é desenraizar-se da vida vivida. Uma coisa é criticar, ter para com o passado uma atitude de crítica, outra coisa é esquecer o passado como se não houvera. Como se sabe, um passado inalterado fabrica um futuro previsível, repetição do presente.

Atualmente, nossos alunos não só tem estas influências, digamos 'caseiras'. Há uma circulação enorme de informações no mundo contemporâneo. Tudo vira notícia, tudo circula na internet. Um programa qualquer de busca é muito mais informado do que qualquer professor poderia sonhar em sê-lo. Ou seja, na relação triádica professoralunos-conhecimentos estamos em desvantagem absoluta em relação aos conhecimentos disponíveis e um aluno medianamente 'incomodativo' poderá nos dar nós constantes... e nossas verdades - os conteúdos de ensino - se vão para o beleleu... Não seria um tempo de repensarmos se cabe ainda à escola o propósito de fazer de seus alunos "agentes da preservação de uma herança cultural"?

\section{O controle ideológico}

Os professores de hoje sofrem ainda mais outra restrição a sua autonomia relativa: o controle ideológico exercido quer pelos agora chamados 'gestores' da escola, quer pelos próprios alunos, dependendo de suas origens sociais. Qualquer discussão sobre problemas contemporâneos que envolvem questões controversas, uma tomada de posição do professor - que ele deve tomar frente a seus alunos - pode ser considerada como "assédio moral"... E há projetos de lei instituindo o "assédio ideológico", crime específico para a categoria dos professores. Ainda não existe a lei, mas juízes já proibiram universidades a debaterem o tema do impeachment da Presidente Dilma! 
Quer dizer, os temas candentes da sociedade, judicializados, tornaram-se proibidos, sobre eles não se podem debruçar professores e estudantes.

Todos conhecemos fatos, particularmente nos momentos mais presentes do Brasil, em que professores sofreram pressões porque tomaram posições ideologicamente marcadas. Para exemplificar este tipo de controle, cito aqui a abertura do manifesto da Associação Latino-Americana de Sociologia e do Consejo LatinoAmericano de Ciencias Sociales (Clacso):

\begin{abstract}
A Associação Latino Americana de Sociologia vem a público expressar sua profunda preocupação e seu repúdio a visíveis sinais, situações e atitudes de discriminação ideológica, relacionadas ao momento político brasileiro e ao nível de polarização encontrado no país. Professores e profissionais associados a perspectivas críticas vêm sendo acusados de "comunistas" e "socialistas", como se esses rótulos representassem posições ilegais ou moralmente inadmissíveis em sociedades democráticas, pluriideológicas e pluripartidárias. Vários destes profissionais estão sendo perseguidos e, eventualmente, demitidos em instituições privadas, como testemunha o caso do Prof ${ }^{o}$ Paulo César Ramos, cientista social, mestre em Sociologia e doutorando em Sociologia pela USP, que foi recentemente demitido da escola em que trabalhava, sem explicações e sem justa causa, por pressão de pais de alunos.
\end{abstract}

Enumerei apenas cinco pontos a partir dos quais se constrói a relatividade de nossa autonomia profissional. Obviamente há outros. Aqui me restringi aos mecanismos mais amplos, aqueles que em geral discutimos quando da elaboração de projetos pedagógicos mas que esquecemos na cotidianidade da sala de aula. É preciso sempre ter presente que o todo está lá no particular, e que o todo não se desfaz dos particulares de que resulta, superando-os, mas não os apagando como se fossem inexistentes.

$\mathbf{X X X}$

\title{
COMO SE DEFINIU A PROFISSÃO DE PROFESSOR ${ }^{122}$
}

A identidade profissional do professor ao longo da história se construiu, essencialmente, pela sua relação com o conhecimento. Nós nos formamos professores ao longo de alguns anos de estudos de certos conteúdos, que adquirimos, que encorpamos, e que nos remodelam, nos tornam a pessoa que não éramos. Seguramente, esse tipo de formação é consequência de um longo processo histórico de construção da identidade profissional do professor, que se mostra nos nossos cursos de formação.

\footnotetext{
${ }^{122} \mathrm{O}$ que se segue, com algumas poucas modificações, é retirado de outro texto: PROFESSOR: CONSTRUÇÃO E RECONSTRUÇÃO DA IDENTIDADE PROFISSIONAL. Disponível em www.portos.in2web.com.br (blog do Wanderley Geraldi).
} 
Certamente antes da existência desta escola que reúne professor, alunos e conhecimento, houve outra escola cujo sentido ainda pode ser recuperado quando falamos, por exemplo, em "escola literária", em "escola romântica", "escola arquitetônica" etc. Nesse sentido, anterior ao sentido contemporâneo de escola, as primeiras escolas foram seguramente o que podemos chamar de "escolas de sábios". Isto é, aquelas escolas em que há a reunião entre um sujeito que pensa com outros sujeitos, não como alunos, mas como discípulos, de que as escolas dos sofistas, a escola de Sócrates, a escola de Platão, são exemplos. Podemos também incluir entre estas "escolas de sábios" os conventos da Idade Média, responsáveis pela preservação e também por uma leitura 'retificadora' - lembremos Santo Agostinho e Tomás de Aquino - de uma rica herança cultural clássica greco-latina e por uma interpretação própria dos evangelhos (comparem-se os franciscanos e os dominicanos).

Etimologicamente, esta ékole significava um tempo livre das ocupações da sobrevivência, um tempo não dedicado à produção, em que livremente se discutiam fatos, temas. Ou seja, a escola etimologicamente tem a ver com tempo livre, livre do processo de produção de bens necessários à vida, para se tornar um tempo sem compromissos diretos com a manutenção da sobrevivência.

Todos sabemos que este tempo 'livre das preocupações produtivas' é extremamente produtivo em termos sociais, porque nele se definem concepções de homem, de sociedade, de natureza, das relações entre tudo isso, e estas concepções estão presentes em todos os detalhes da vida produtiva. Recuperar pela etimologia uma escola como 'tempo livre' sem se preocupar com os efeitos do que acontece no tempo livre na vida produtiva é desconhecer que a escola existe no interior de uma sociedade mais ampla, e que seus membros não são monges que se retiraram do mundo para viverem no claustro, mas sujeitos sociais ativos, presentes, que vão à escola e saem dela todos os dias ${ }^{123}$.

Nestas "escolas" ensinavam aqueles que estavam produzindo conhecimento. Não havia distinção entre o filósofo e o professor de filosofia. Ensinava-se filosofia porque se era filósofo. E na Idade Média, cada fundador ou "patrono" de uma ordem religiosa

\footnotetext{
${ }^{123}$ Estou aqui fazendo referência indireta ao livro, para mim extremamente equivocado, de MASSCHELEIN, J.; SIMONS, M. Em defesa da escola. Uma questão pública. Belo Horizonte: Autêntica, 2013. Nesta obra, os autores defendem a escola como tempo livre esquecendo por completo de que a escola está situada num espaço específico até geograficamente! Que uma escola não é um claustro de monges que abandonaram a vida civil e se recolheram à contemplação! Para quem lê o livro, parece que a escola deveria voltar a ser a escola do século XVIII, imitando os conventos, as abadias, os claustros beneditinos.
} 
ou de uma abadia era também o "fundador" de uma certa leitura, de uma certa interpretação dos evangelhos. Que sirvam de exemplo Santo Anselmo, Francisco de Assis ou Tereza de Ávila.

Em resumo, havia um produtor de conhecimentos, e esse produtor de conhecimentos, porque produtor, era buscado por seguidores, voluntários às vezes, forçados outras vezes, por interesses no conhecimento ou por demonstração de prestígio. Para quem está lembrado do romance (ou do filme) "O nome da rosa", Adso de Melk vai conviver/aprender com Guilherme de Baskerville. Não é sem dúvidas e sem lembranças que o narrador da história, o noviço Adso tornado o sábio velho frei que rememora: ao longo do enredo do romance convive com Baskerville, inicialmente em função de uma demanda dos pais, que o haviam confiado para aprender com o já sábio Baskerville, depois por vontade própria expressa na sequência (ou cena) em que decide seguir o mestre, sacrificando o amor físico que desejara, experimentara e continuava a desejar.

Parece-me que a primeira grande divisão social do trabalho educativo se dará no período do Mercantilismo, já como consequência, inclusive, da expansão europeia, quer pela ação dos comerciantes venezianos (do Adriático para o Oriente) quer pelas conquistas do Ocidente pela ação da Península Ibérica, a que não faltou também o financiamento dos banqueiros toscanos. No Mercantilismo, essa divisão social do trabalho, em nosso campo, constrói pela primeira vez, digamos assim, uma identidade para o professor.

É bastante instrutivo, para todos nós, independentemente da área em que atuamos, fazer um retorno à Didáctica Magna, obra de Coménius, nascida na década de 1620. Interessam algumas de suas metáforas, bastante elucidativas da identidade do professor que se começa a desenhar nos começos do século XVII. É com estas metáforas que se constrói a identidade do professor que perdurará por um longo período da nossa história. É preciso lembrar, no entanto, que estas metáforas foram elaboradas no contexto específico da expansão europeia. A modernidade vitoriosa vinha impondo uma laicização do Estado e a reforma de Lutero mostrava que a unidade da Igreja já havia ficado para trás. Como a religião católica havia sido o amálgama da era medieval, havia necessidade de construir novo amálgama - um novo sistema ântropo-cultural de referências - que fosse comum. Este amálgama será o conhecimento e a informação que se vem impondo ao logo deste tempo que chamamos de Idade Moderna. Assim, esta necessidade e a persistência da religiosidade, com a vontade de expansão do 
cristianismo, da evangelização, com que o frade Coménius estava comprometido até por dever de ofício, vai criar um sistema capaz de incutir o novo sistema de referências comum.

No entanto, havia um problema: onde arranjar quem faça isso? Onde encontrar quem saiba estes conhecimentos e possa transmiti-los? Surge então a proposta da Didática Magna. A título de exemplo, consideremos a seguinte passagem:

\begin{abstract}
...serão hábeis para ensinar mesmo aqueles a quem a natureza não dotou de muita habilidade para ensinar, pois a missão de cada um (não) é tanto tirar da própria mente o que deve ensinar, como sobretudo comunicar e infundir na juventude uma erudição já preparada e com instrumentos também já preparados, colocados nas suas mãos. Com efeito, assim como qualquer organista executa qualquer sinfonia, olhando para a partitura a qual talvez ele não fosse capaz de compor nem de executar de cor só com a voz ou com o órgão, assim também por que é que não há o professor de ensinar na escola todas as coisas, se tudo aquilo que deverá ensinar e, bem assim os modos como o há de ensinar, o tem escrito como que em partituras? (Comenius, XXXII-4)
\end{abstract}

Há muitas pessoas que precisam aprender, mas a humanidade não dispõe de doutos em número suficiente para lhes ensinar. Então, com resolver o problema? A metáfora do organista, que executa qualquer sinfonia mesmo não sabendo compô-la é extremamente instrutiva: ao ouvinte não interessa saber se o executor é capaz de compor, interessa que acompanhe com maestria a partitura, onde tudo já está escrito. Onde tudo já está composto. É aplicando os sentidos desta metáfora à atividade de ensino - e portanto à atividade pedagógica - que se enumeram as características identitárias dessa profissão de "professor":

1. ser hábil para ensinar mesmo não sendo muito dotado;

2. sua função é comunicar (e infundir) na juventude uma erudição já preparada, e não retirada da própria mente (isto é, não precisa ser produzida por ele próprio);

3. para exercer sua função, tudo se lhe dá nas mãos: o quê e o como ensinar (uma partitura já composta)

Deste ponto de vista, o processo escolar se dará como se um de seus agentes, o professor, executasse uma partitura. O professor não precisa ser douto, mas saber tudo o que deve fazer, e este "tudo" lhe é dado nas mãos pelos doutos, que preparariam o que ensinar e como ensinar. Esta passagem de um sujeito que produzia conhecimentos para 
um sujeito que sabe o saber produzido por outros e que o transmite, instaura na constituição mesma da identidade profissional do professor, o signo da desatualização, porque como o professor não está produzindo os saberes que ensina, ele está sempre atrás destes saberes que estão sendo produzido por outros. É necessária uma contínua atualização para estar sabendo o que se produz de novo que, para se tornar objeto de ensino, passará pelo processo de sua transformação em conteúdo de ensino.

Esta identidade social do professor, o sujeito que sabe o saber produzido por outros, e que o transmite, permanece ao longo da história, mais ou menos do século XVII até meados do século XX. Desta identidade temos ainda resquícios, nas pequenas aldeias em que o professor é consultado inclusive sobre diferentes problemas, até mesmo de relações familiares. Quer dizer, o professor é um sujeito social que tem um saber e por este saber ele é respeitado. Ele transmite este saber e é pelo saber que tem poder, inclusive de aplicar castigos para filhos dos outros. Não é incomum, pelo menos no Brasil, que pais digam aos professores: "A senhora pode puxar por ele, pode pô-lo de castigo". É por este suposto saber que o professor está autorizado a falar, a impor disciplina e comportamentos.

É com o desenvolvimento das tecnologias que, a partir da segunda revolução industrial, e bem mais fortemente nos inícios do Século XX, outra divisão social do trabalho vai-se operar, construindo uma nova identidade: o professor já não mais se define por saber o saber produzido pelos outros, que organiza e transmite didaticamente a seus alunos, mas se define como aquele que aplica um conjunto de técnicas de controle na sala de aula.

Em certo sentido, numa metáfora extremamente forte, a nova identidade do professor é a identidade do capaz, do exercício de uma capatazia, do controle do processo de aprendizagem da criança. Se há um deslocamento, digamos assim, na relação triádica professor, aluno e conhecimento, este deslocamento se dá no tipo de atuação do professor, pois a relação do aluno com o conhecimento não é mais mediada pela transmissão do professor, mas sim pelo material didático posto na mão do aprendiz, cabendo ao professor o controle do tempo, da postura e dos comportamentos dos alunos durante esta relação com o conhecimento através do material didático. Quem instrui é o material didático. Ao professor compete distribuir o tempo ${ }^{124}$, distribuir as pessoas em duplas, em grupos, em grande grupo e pior ainda, distribui-las entre os que aprendem e

\footnotetext{
${ }^{124}$ Se estivermos atentos, escutaremos em nossa memória as frequentes perguntas: "Terminaram?" "Já leram?" "Mais três minutos para acabar"...
} 
os que têm dificuldade de aprender, expulsando estes da escola ou encaminhando-os, atualmente, aos serviços de saúde para diagnósticos de doenças inexistentes como dislexia, TDAH, TOD etc quando os problemas são de ensino e não de aprendizagem. Também lhe cabe verificar se houve "fixação" do conteúdo, comparando respostas dos aprendizes com o "livro do professor", onde exercícios e tarefas estão resolvidos e oferecem a chave de correção de qualquer desvio, auxiliado nesta tarefa, nos tempos mais atuais, pelos sistemas de avaliação externa tipo PISA, Prova Brasil etc. Num mesmo gesto, uma nova identidade e uma fixação dos sentidos.

Neste tempo já não é mais obrigação do professor saber o saber produzido pela pesquisa: esta é uma responsabilidade do autor do livro didático, do material didático. Há uma nova instância discursiva construída pelas novas relações de produção. E nesta instância são seriados os conteúdos de ensino como se os conhecimentos tivessem diferentes níveis. E esta seriação em abstrato se impõe como aquela adequada a faixas etárias, a estágios de desenvolvimento etc. Abre-se todo o espaço para um tecnicismo da transmissão dos conhecimentos feitos conteúdos de ensino ${ }^{125}$.

Foi neste modelo que nós nos criamos, seguramente ao menos a minha geração. A escola como um lugar de ascensão social, que a estrutura na verdade permitiu a uns poucos para poder continuar mantendo sua própria reprodução. Há que haver exemplos, mínimos, mas exemplos. Eu próprio me incluo com um destes exemplos, afinal sou filho de pai analfabeto, terceira geração de imigrantes. E sempre que me mostram a possibilidade de ascensão via escolarização, eu me pergunto pelos meus outros colegas de primeiro ano primário. Onde está o Alberto, meu colega de $1^{\circ}$ ano, que se sentava na mesma carteira? Eram aquelas velhas carteiras escolares, um banco longo, que ocupávamos dois a dois. Onde estão aqueles que comigo conviveram, que eram do meu bairro e com os quais perdi o contato? Tenho notícias de apenas um, que morava próximo ao centro, casa que causava invejas. Ele se tornou dentista. De mais ou menos trinta, dois gatos pingados bem sucedidos nos processos escolares. Mas não é o pequeno número de bem sucedidos, sucesso que escapa por entre as frinchas da estrutura, que motiva a crítica e a crise da escola de hoje.

\footnotetext{
125 O tecnicismo dos fins da década de 1960 e da década de 1970 está retornando fortemente entre nós, especialmente na área do ensino de língua materna, pelo trabalho de alguns linguistas aplicados que têm definido sequências didáticas para aprendizagem de todos e cada um dos gêneros de discurso do repertório disponível (sem os gêneros afeitos precisamente à atividade em que estão envolvidos os alunos: anotações, resumos, grades, quadros sinópticos, esquemas, etc esquecendo por isso mesmo o ensinamento primeiro da fonte a que supostamente recorreram: o pensamento de Bakhtin).
} 


\section{UM OFÍCIO EM EXTINÇÃO?}

Este modelo de professor como sujeito que controla o processo da aprendizagem entra em crise nas duas últimas décadas do século XX. E nós ainda estamos vivendo precisamente este momento de crise, cuja amplitude se alastra à medida do acesso da população às novas tecnologias de informação e comunicação. Tudo aquilo que os conteúdos de ensino transmitem está disponível na internet e de forma mais prazerosa do que aquela da transmissão possível na sala de aula. A internet e o acesso à informação trouxeram no seu bojo a necessidade de redefinir a função da escola e com ela a identidade profissional do professor.

Face às novas tecnologias, já é possível pôr sob suspeição o segundo propósito que fundou a existência da escola: uma transmissão que pretende a manutenção de uma herança cultural. Para esta operação de conservação da herança cultural trabalham hoje outras instituições sociais, ao transmitirem informações (científicas ou não): programas instrutivos (vídeos, tevês, revistas, enciclopédias, e até mesmo a Wikipédia que pode ser manuseada com rapidez e eficiência) e sistemas de armazenamento de informações acoplados a sistemas de busca (estilo Google). Com a tecnologia existente, as aulas poderiam facilmente ocorrer sem professores (como ensaia a Educação à Distância). E como os arquivos de aulas podem ser partilhados, um só professor de física daria conta do ensino desta disciplina no país inteiro. Se por ensino entendermos a transmissão de conhecimentos, visando sua manutenção enquanto herança cultural.

As possibilidades tecnológicas são inúmeras. E elas funcionam muito bem, até de forma mais prazerosa para o aprendiz, na transmissão de conhecimentos tomados como prontos, acabados, verdades a serem apreendidas, aprisionadas no cérebro, num contrassenso incrível com a própria tecnologia disponível. Ora, nós já não precisamos mais ter as coisas na cabeça, porque elas estão fora de nós, no computador. Se quiser uma informação, ela está lá, disponível. No entanto, nosso grande problema é que podemos estar obesos de informações, mas anoréxicos de reflexão, porque o computador não trabalha com reflexão, mas com produtos da reflexão. E uma aula é um espaço privilegiado de reflexão, em que a informação, hoje, deixou de ser fundamental.

Como ainda pensamos a educação como transmissão de informações (conteúdos), a escola brasileira enfrenta inúmeros reveses, incluindo entre eles a própria 
formação dos professores e as possibilidades efetivas de sua educação continuada. O professorado brasileiro está preparado para autonomamente conduzir suas aulas? Não! E não está porque numa só geração este professorado deu um salto de escolaridade espantoso: filhos de pais de baixa ou nenhuma escolarização, os professores fizeram o curso superior acessível e possível. E este salto produz, como todo salto, um "vazio" que não é culpa do professor, mas consequência da mesquinhez histórica da classe dominante que somente nos inícios do século XXI começaram a admitir o acesso ao ensino superior para os menos privilegiados (acesso que escandaliza a classe média e a põe na rua para derrubar a petulância de um governo que se atreveu a repartir com outros os bancos das universidades que lhes eram destinados).

Como consequência destas e de outras mazelas, o campo está fértil para a venda de pacotes pedagógicos. O crescimento das empresas dos "sistemas de ensino apostilado" (tipo Anglo, Positivo, COC etc), a presença maciça de "fundações" e "ONGs" oferecendo material a suposto custo zero ou a suposto preço de custo são alguns dos fenômenos mais relevantes para o magistério nos últimos anos. Há uma delegação de competência: do professor para o autor do material didático adotado, seja ele um livro didático, seja ele um pacote pedagógico, seja ele um conjunto de apostilas. Em todos estes materiais, o que fazer do professor está esmiuçado, o conteúdo está definido e a preparação dos alunos para os famosos testes de avaliação externa estaria garantida...

Assim, em tempos de pacotes pedagógicos assumidos até mesmo por governos estaduais que se julgam progressistas, nada mais interessante do que retomar a afirmação de Lyotard, na Condição Pós-moderna, de que uma das profissões que as novas mídias fariam desaparecer seria a do professor. E nada melhor do que fazer isso relendo e acompanhando o interessante trabalho de Luiza Cortesão: Ser Professor: Um Ofício em Risco de Extinção?, publicado pela Cortez Editora, na coleção Prospectiva do Instituto Paulo Freire.

Neste pequeno grande livro, Luiza Cortesão faz uma análise do papel do professor no mundo contemporâneo, retomando a bibliografia mais importante sobre o assunto. Tradicionalmente, um "bom professor" seria aquele que, conhecendo o conteúdo considerado culturalmente importante e por isso incluído nos currículos escolares, era capaz de explicar com clareza e de forma inteligível estes conteúdos: tratava-se de um papel subordinado de tradução, simplificação e ritmagem no avanço dos conhecimentos. A ideia de educação que subjazia a esta perspectiva era a de que a 
distribuição igual de acesso às informações científicas abria oportunidades de sobrevivência e sucesso iguais para todos, de modo que "garantia-se a justiça na oferta de um processo de formação normalizador”. Supostamente, mesmo na democratização de acesso à escola, todos entrariam nas mesmas condições e sairiam com as mesmas condições!

A massificação do ensino mostrou que o pressuposto de igualdade de condições para a aprendizagem dos conhecimentos considerados "importantes" era falso. Como resolver estas diferenças iniciais? Para o sistema que ainda aposta precisamente neste tipo de educação, trata-se de melhorar o material instrucional, de adequá-lo à realidade, de utilizar de todos os meios disponíveis (e aí o papel das novas mídias) para que estes conteúdos se tornem palatáveis, inteligíveis, compreensíveis. Neste sentido, para manter a educação no mesmo lugar - o da reprodução do conhecimento e da sociedade, definindo os lugares sociais que cada um ocupará no futuro - realmente não há porque lutar por autonomia do professor na condução do processo de ensino e, certamente, as mídias contemporâneas com suas tecnologias interativas são bem mais capazes de ensinar o já dado, fazer os alunos repetirem para sempre as mesmas verdades e responderem adequadamente aos testes nacionais e internacionais. $\mathrm{O}$ investimento, portanto, em tecnologias digitais e em pacotes pedagógicos, em sistemas apostilados, justifica-se: para fazer a educação da reprodução. Neste contexto, e concebendo a educação como mera reprodução do já sabido, a figura do professor perde qualquer grandeza e torna-se mesmo dispensável. Para a reprodução, a profissão de professor está em extinção.

No entanto, a sociedade é muito mais complexa do que a visão tradicional de educação consegue enxergar. As diferenças culturais existentes no mundo não permitem mais defender um único ponto de vista como aquele a que todos devem se submeter! $\mathrm{O}$ próprio conhecimento científico, desde Einstein chegando a Prigogine, sabe que não trabalha com o real e nem com a verdade: há verdades. Para aqueles que não são “indiferentes à diferença", aqueles "não daltônicos" na expressão de Luiza Cortesão, a educação é muito mais um tempo e espaço de criação e discussão do que de reprodução do já sabido (que está disponível nas muitas mídias, particularmente na internet).

O que as novas mídias estão colocando para a escola, para a educação, não é simplesmente a questão de como usá-las para ensinar o que já se ensinava; não se trata de simplesmente dar acesso ao mundo digital para resolver o problema. Trata-se, no mundo contemporâneo, de atenção crítica ao que está posto e não de simples 
incorporação/internalização do que defende o pensamento hegemônico nas televisões, nos jornais, nas redes sociais etc. Ao excesso de informação disponível é preciso contrapor na atenção crítica e criativa.

Neste contexto, de uma educação que queira ir além do estabelecido, que queira construir uma cidadania que compreende os processos de exploração do trabalho no mundo atual, uma cidadania crítica e interveniente, que queira a construção de um mundo melhor e mais justo, a figura do professor se torna imprescindível como incentivador, como perguntador, como alavanca em que possam os jovens se apoiar para seus voos e tateios na construção de um futuro distinto daquele que nos reservam o pensamento neoliberal hegemônico e os "pacotes pedagógicos" que seus agentes educativos têm colocado à nossa disposição.

Por isso, toda vez que um professor manuseia o material instrucional do pacote que lhe impôs o Estado, deve sempre pensar a quem está servindo e até que ponto está decretando sua própria morte no futuro.

Toda as potencialidades das novas tecnologias fizeram vir à tona com muita força o primeiro propósito que fundou a escola moderna: 'educar' crianças e jovens para que se insiram 'adequadamente' no meio social. E aqui ganha peso o conceito de educação (não de ensino e transmissão de saberes), e as formas como encaramos o modo de organização e de ser do meio social. Este é o debate contemporâneo que seguramente fará do professor não mais um 'comunicador de conhecimentos', mas de um mediador na compreensão do vivido contemporâneo, recuperando na herança cultural elementos que possam ajudar na construção dos sentidos do que se vive. Não se abdica aqui do conhecimento, mas este deixa de ser o vértice fundamental para abrir lugar para os sujeitos envolvidos no processo educativo.

$\mathbf{X X X}$

\section{DIANTE DA REALIDADE BRASILEIRA, COMO RESPONDEM AS POLÍTICAS PÚBLICAS NA ÁREA DA EDUCAÇÃO?}

Há duas características constantes nas políticas públicas de educação nos últimos vinte anos:

1. Mantém o pressuposto de que igualdade de condições para a aprendizagem dos conhecimentos considerados "importantes" é a forma de superar as desigualdades econômicas das hereditariedades das condições sociais: a classe dominante gera dominantes; as classes subalternizadas geram descendentes 
subalternizados (umas pouquíssimas exceções para serem apontadas como exemplos contados nos dedos das mãos mas que ideologicamente justificam a manutenção do sistema de divisões sociais.

2. Mantém o pressuposto de que a educação se faz através da transmissão de conhecimentos, tratados estes como ‘informação’ que deverá estar disponível em cada sujeito escolarizado para operar com estes conhecimentos sempre que as situações cotidianas lhe exigirem. Os saberes têm estar 'na cabeça', e não disponíveis para consulta fora da 'cabeça'. Por isso essa não é para pensar, mas para armazenar informações transmitidas como verdades.

Como estes pressupostos se traduzem em políticas educacionais, no Brasil dos últimos anos, apesar de toda a sociologia da educação ter mostrado que condições de igualdade para aprender são insuficientes face as condições de entrada na escola e as condições sociais de vida dos estudantes?

Não vou analisar, aqui, cada um dos programas governamentais que elaborados, editados e tornados práticas (não correntes nas salas de aula!) efetivas do sistema educacional. Farei apenas uma listagem com comentários, pois cada um destes programas tem merecido estudos aprofundados disponíveis na literatura educacional brasileira. Como se sabe, com o neoliberalismo, Inicia-se o tempo da inundação das escolas por documentos oficiais definindo metas, objetivos, modos de gestão, índices desejados etc. etc. Vamos a eles:

A criação de sistemas nacionais de avaliação. No projeto neoliberal, a função do estado deve ser reduzida ao mínimo de interferência, quer como gestão, quer como investimento. Segundo a metáfora de seu gosto, a sociedade é um organismo vivo e o mercado o seu sangue que autorregularia tudo e construiria as condições justas de convívio social. Caberia ao estado constituir em "agência de regulação e controle", a regulação deve ser mínima de tal ordem que o 'negociado' entre as partes valha mais do que o 'legislado', mas o controle deve ser constante. É neste contexto que aparecem os programas de avaliação. Iniciados pelos chamados "exames" de cursos superiores, que atingia um público menor e garantiria o apoio das universidades públicas, sempre melhores e críticas das instituições privadas de ensino superior. Como esperado, os estudantes concluintes das instituições públicas se saíram melhor do que os concluintes das instituições privadas. Face a esta constatação, a política do MEC de Paulo Renato Souza (PSDB) foi de apoio às instituições privadas que passaram a ter acessos a financiamentos públicos pelo BNDES, pelo FINEP e outras fontes de recursos, 
inclusive alguns programas com verbas inacessíveis para as instituições públicas (por exemplo, as verbas destinadas ao ensino técnico).

A partir da avaliação dos cursos superiores, seguiu-se a avaliação nacional do ensino básico, de que o ENEM (e seus efeitos para a seleção de candidatos às universidades) é o melhor exemplo. Não só avalia-se o passado: esta avaliação é que abre os horizontes de futuro possíveis. Como em cascata, o modelo nacional se impôs aos Estados e aos Municípios. E uma chuva de siglas começa a aparecer, todas referentes às avaliações de larga escala praticadas pelo s governos federal, estadual e municipal (principalmente dos grandes municípios).

Eis o primeiro grande cerceamento à autonomia do professor: a existência de provas que avaliam a retenção de informações, chamadas conhecimentos, sobrepõe-se à educação da cidadania, para que se preparem sujeitos capazes de responder a testes.

A este propósito, há uma luz no fim do túnel. Diane Ravicht, a todo poderosa diretora dos sistema de avaliação dos EEUU, de que copiamos nossos sistemas, revisou suas posições e tem defendido, depois de ter dirigido por vinte anos as avaliações norteamericanas, que a educação não deve se restringir a isso e que testes nada dizem sobre as mais necessárias capacidades de um sujeito escolarizado. Quando a matriz começa a mudar, podemos esperar mudanças por aqui daqui a alguns anos. E saberemos que os mesmos 'assessores' universitários que ajudaram a implantar os sistemas, que participaram das elaborações das provas, defenderão e assessorarão o seu término.No entanto, o programa avaliativo esbarrou numa dificuldade operacional: não havia currículo nacional oficial para o ensino básico. Para os cursos superiores, o Conselho Nacional de Educação sempre fixou uma grade curricular a ser cumprida pelas instituições. Mas no ensino básico as propostas e planos curriculares eram estaduais, a maioria deles elaborada nos começos da redemocratização, em meados dos anos 1980. Daí a 'encomenda' do MEC ao seu Instituto Nacional de Estudos e Pesquisas (INEP) a elaboração de propostas curriculares nacionais, que aparecem como Parâmetros curriculares nacionais. Não por acaso, eles se chamam "parâmetros" porque elaborados como base de avaliação. Abandona-se a terminologia de 'planos' e 'propostas' curriculares para implantar Parâmetros curriculares. Os parâmetros não são propostas, são exigências dos sistemas de avaliação. Como o governo neoliberal não queria aparecer como retrógrado, os nossos parâmetros nacionais se ajustam às pesquisas de ponta em cada uma das áreas curriculares. E então temos um paradoxo fundante destes parâmetros: as concepções que os iluminam são discordantes das exigências avaliativas 
que demandam uniformidade em cada sistema, em cada escola, em cada série ou ano, em cada sala de aula. Como resolver este problema, já que os parâmetros elaborados abrem inúmeras possibilidades de práticas pedagógicas que elevariam a autonomia relativa dos professores? Estávamos numa situação paradoxal: cerceamento da autonomia do professor pelas avaliações que seriam parametramizadas pelos PCNs, e estes por seu turno contemplavam a autonomia relativa do professor em cada área curricular.

Neste contexto, elaboram-se outros programas cuja função será precisamente tornar os PCNs um sistema de controle da autonomia, reduzindo-a ao mínimo possível. Surgem então os programas: (a) "Os PCNs em ação" que vão definir e ajustar o que estava previsto, uniformizando seus sentidos e levando a práticas sempre iguais; (b) o Programa Nacional do Livro Didático, com compra e distribuição dos livros pelas escolas do país. Um programa de grande apelo popular que libertava os pais da compra de livros. E os livros passaram a ter uma chancela pública: eram avaliados por uma comissão de especialistas. E eles deveriam estar de acordo com os PCNs. O que era então liberdade de organizar o ensino dentro de algumas linhas mestras previstas nacionalmente torna-se um ensino uma atividade rotineira de seguir o livro indicado e distribuído para a escola. Para manter as aparências de um sistema democrático, os professores poderiam escolher os livros que desejassem dentro da lista dos aprovados pela comissão especializada. Como se sabe, ocorreram inúmeras falhas operacionais os livros entregues não eram os escolhidos, os livros chegavam às vezes já no final do primeiro semestre; (c) a elaboração de matrizes de referência que definem minuciosamente objetivos e conteúdos das matérias ensinadas, numa codificação incompreensível para o professor. A partir daí em cada conteúdo o professor deveria atingir as metas previstas nas matrizes, de modo que seus alunos estivessem amestrados para responderem aos testes de avaliação; (d) como se isso não bastasse, criam-se os famosos índices (IDEP e assemelhados) que passam a atormentar o dia a dia da escola e da sala de aula. Fixam-se valores a serem alcançados; os professores labutam para enfiar nos alunos os 'conteúdos' das avaliações, treinam os alunos para os testes com 'simulados' mensais e semanais quando a data da prova está chegando. Dispõem deste material nos portais do MEC: a aparente 'transparência' nada mais é do que controle, do que forma sutil de um poder panóptico que é internalizado pela escola, pelos gestores e pelo próprio professor. Nada é mais cerceador da autonomia relativa do professor do que um sistema panóptico de controle. E como os índices devem ser publicados, 
expostos nas escolas, pais se tornam fiscais da escola!!! E as escolas, por seu turno, ainda que públicas, passam a selecionar seus alunos para não se saírem mal e atingirem os maiores índices possíveis; (e) por fim, e não sem menor influência, alguns estados começam a pagar bônus a professores das escolas que se saíram bem nas avaliações, transformando o bom desempenho dos alunos em remuneração extra para o professor! Este sistema perverso, aliado aos baixos salários pagos aos professores, leva ao aumento vertiginoso do mal estar docente: 'alunos fracos' se tornam agora um problema de remuneração, não mais apenas um problema a ser resolvido por práticas pedagógicas. $\mathrm{O}$ aluno 'fraco', que 'não aprende' vai ter influência no supermercado do professor! Este conjunto de programas e medidas tornam-se sempre cerceamentos da autonomia do professor e fazem do exercício da profissão um martírio que sangra a todos - gestores, professores e alunos - no altar do aprofundamento das desigualdades sociais.

1. Como todas estas grandes e custosas medidas não melhoraram os índices nos exames internacionais (PISA), em lugar de fazer uma análise crítica das políticas implementadas, ao contrário aprofundam-se as mesmas medidas, mesmo num governo com pendores não neoliberais. Os governos petistas tiveram um programa democrático para o ensino superior, mas mantiveram e aprofundaram a perspectiva neoliberal no ensino básico. Assim, leva-se a criança de 8 anos a provas nacionais para verificar se estão alfabetizados na idade certa. São crianças submetidas à tortura diária para que os índices melhorem. Apertam-se os exames já existentes. Transforma-se o ENEM numa porta de entrada para as universidades. Tudo vai sendo fechado de modo a não haver escapatória para práticas pedagógicas discordantes. Trata-se não de formar uma cidadania crítica (isto fica para os discursos políticos), mas de instruir, encher os alunos de informações para torna-los aptos e treinados a responderem testes. E pasmem: surgem os primeiros exames na educação infantil. A propósito, vale lembrar uma história que me contaram da aplicação dos testes com crianças de 3-4 anos de idade. Na orientação para a professora, ela deveria ler a ordem e a pergunta duas vezes. E a criança deveria realizar a ordem dada. Uma das questões era:

Repita: 8, 2.

A criança deveria dizer na mesma ordem: 8,2 . E eis que uma criança responde à aplicadora do teste: - Não, 8, 9 .

Conclusão: a criança não sabe repetir. Para além da burrice do teste, note-se a importância dada à repetição! É isso, na verdade que está em jogo: uma escola que 
ensine a repetir. Os conhecimentos não são alavancas para produzir outros conhecimentos, para compreender o mundo de uma certa forma, para transformar o mundo que habitamos. Não, os conhecimentos são informações que devem ser repetidas.

Repetir a informação, para o estudante. Repetir as perguntas das provas para os professores, seguir aulas disponíveis no Portal do MEC, isto é repetir. Repetir o livro didático disponibilizado pelo PNLD, e assim sucessivamente. Os programas desenvolvidos fazem internalizar que repetir é ser bom. Sujeitos sociais constituídos para repetirem informações estão prontos para o Jornal Nacional da Globo e para a leitura da $V E J A !^{126}$ Não é por acaso que são bem escolarizados os sujeitos que tomaram as ruas pedindo o retorno do regime militar!

2. A base nacional comum curricular. Como o sucesso das medidas é mediano, o PNE traz em seu bojo o que fora legislado desde a Lei de Diretrizes e Bases da educação nacional, uma lei aprovada no governo neoliberal de Fernando Henrique Cardoso. E surge a base nacional comum curricular, definindo ano a ano o que deve ser ensinado, o que deve ser atingido. No documento posto à discussão pública, aparecem os códigos que somente aqueles acostumados ao manuseio da matrizes de referência para as avaliações de larga escala entendem o que significa. A questão envolvida é a da construção da uniformidade. As justificativas são as tradicionais. Particularmente a justificativa de apelo ideológico, que já conhecemos, o princípio de atribuir à educação a responsabilidade pela construção, para todos, das mesmas condições de "concorrência no mercado". Competente também quer dizer que compete!

É no ambiente dos sistemas de avaliação, dos programas de unificação do que querem que aconteça em cada sala de aula, em cada momento da vida pedagógica. que surge a Base Nacional Comum Curricular (BNCC), também ela produto de consultorias universitárias, de comitês de especialistas, de técnicos competentes. Seguindo o mesmo diapasão: implantação vertical. Imposição, enfim. Como ocorreram com os Parâmetros Curriculares Nacionais, assim que aprovada a BNCC, surgirão os programas "BNCC em ação" para tentar chegar ao chão da escola, copiando o programa "PCNs em ação". Provavelmente os assessores e consultores, dos centros universitários e das ONGs e

\footnotetext{
${ }^{126}$ Aos leitores, peço desculpas por sujar este texto trazendo estes nomes impronunciáveis à baila.
} 
OSs, já estão com os projetos elaborados para apresentarem assim que saírem os novos editais que serão sugeridos por eles mesmos.

Com muito boa vontade, professores universitários participam dos comitês, a partir do princípio ideológico de que estando lá, poderão fazer com que as coisas saiam melhor do que sairiam se estivessem ausentes. Mas deste modo acabam por referendar o modelo de implantação vertical. Tive oportunidade recente de um diálogo franco com um participante do grande comitê que está definindo a matriz de referências para a elaboração dos concursos nacionais para o magistério. A perspectiva que leva ao engajamento de professores universitários nestes processos tem sua base no fato de que tais referenciais acabarão por mostrar o perfil de professor que se deseja para o país e por isso influenciará tanto na sua formação quanto nas práticas dos futuros docentes. Independentemente da validade deste perfil, de estar de acordo com ele, das boas propostas incorporadas nestes documentos, o que resulta da implantação vertical (e muito pouco democrática, porque executada através de provas) é uma resistência contrária dos verdadeiros agentes das redes de educação (que infelizmente tomamos como sinônimo de sistemas de ensino). E assim será com a Base Nacional Comum Curricular, pondo por água abaixo boas propostas que a compõem.

3. A certificação dos professores. Até agora, as avaliações atingiam somente os alunos. Agora a enchente que afoga a todos chega aos professores. A proposta de certificação dos professores, através de provas (sempre a avaliação como controle de qualidade, uma expressão procedente do mundo empresarial), não chegou a ser feita pelo governo neoliberal. Nem eles tiveram esta coragem; ela aparece nos primeiros meses do governo Lula. Felizmente não aplicada nos anos subsequentes, ela volta agora através do Plano Nacional de Educação (PNE) na forma de concurso nacional de professores, destinado tanto a professores em exercício, quanto a formandos recém licenciados e para candidatos ao exercício do magistério! Pela lei, os municípios e estados, que por constituição são obrigados a contratarem seus quadros através de concurso público, poderão usar os resultados da certificação e se dispensarão de fazer seus próprios concursos. Como resultado, teremos um vai-e-vem de professores pelo país afora: um licenciado que tenha um resultado elevado na prova é candidato preferencial a assumir uma vaga num sistema educacional (municipal ou estadual) em qualquer parte do país. Quando aparecerem vagas em lugares mais aprazíveis ou mais interessantes para este mesmo professor, ele se candidata e abandona escola e alunos 
porque ele se tornou um professor certificado apto a dar aulas em qualquer lugar, mas sem compromisso de enraizamento social!

$\mathbf{X X X}$

A história nos ensina que as transformações sempre foram conquistadas, jamais implantadas! Por implantação se pode conseguir mudanças, mas não transformações. Sem dúvida, o conjunto das políticas aqui listadas - e não se restringem a estas as ações governamentais na área - mudou o panorama das escolas. A questão é saber qual a direção destas mudanças.

Se a sociedade que se quer é aquela da solidariedade, do convívio salutar e dialógico entre as pessoas, da justiça social e da oferta de possibilidades de vida feliz para todos, em que o trabalho deve produzir frutos comuns, então todas estas políticas implantadas nas escolas brasileiras vão em sentido contrário: seguindo-as estaremos formando sujeitos competitivos, treinados, informados, egoístas, movidos por interesses mesquinhos e individualistas.

O panorama não é de tranquilidade para os professores. Cerceados por todos os lados, com a autonomia chegando à beira do zero, eles terão que participar do largo debate sobre a sociedade que se quer para poderem transformar a escola que temos (ou aprofundá-la segundo estes parâmetros) se assim o desejar a sociedade brasileira, porque ao contrário do que se apregoa, não se trata de melhorar a escola, mas de transformá-la profundamente em seus propósitos se o que se quer é um cidadão crítico e socialmente atuante.

\section{Referências}

CORTESÃO, Luiza. Ser Professor: um ofício em risco de extinção? São Paulo : Cortez Editora.

COUTO, Mia. Idades cidades divindades. Lisboa : Caminho, 2007.

GERALDI, João Wanderley. O ensino de língua portuguesa na proposta da Base Nacional Comum Curricular. Retratos da Escola, CNTE, 2016.

Professor: construção e reconstrução da identidade profissional. Disponível em www.portos.in2web.com.br

MASSCHELEIN, J.; SIMONS, M. Em defesa da escola. Uma questão pública. Belo Horizonte: Autêntica, 2013. 